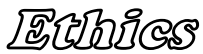

\section{On the abuses by the thesis supervisor in the light of the academic ethos}

\author{
Agnieszka Świtalska \\ agnieszka_switalska@,wp.pl
}

\begin{abstract}
The paper will attempt to provide an ethical reflection upon abuses by a thesis supervisor that may occur in interpersonal relationships between a student and his or her supervisor. The abuses will be considered from the perspective of the academic ethos. In this the author will focus upon the actual notion of ethos and values which are considered as constituent for the ethos of scholars. In the second part of the paper the author will reflect on which of the thesis supervisor's attitudes constitute a betrayal of these values.
\end{abstract}

Key words: ethos, value, scholars, supervisor, student, abuses, duty.

The topic of this paper indicates the following direction of research: firstly the actual notion of ethos needs to be defined, secondly what are the constituent values for the ethos of scholars and finally which of the thesis supervisor's attitudes constitute the betrayal of these values.

\section{The notion of ethos}

Taking into account the classic meaning of the term, ethos is "generally the factual form of morality and a set of the customs of a given social group that are reflected in the lifestyle of the social group members in the particular historical circumstances" (Herbut 1997, p. 174). M. Ossowska, the sociologist of morality, emphasises the hierarchisation of the values that add up to the ethos (Ossowska 1973). At this point the issue becomes the status attributed to the values creating the ethos of a particular community. One can make an assumption that these principles are changeable and there are none that would be in effect at all times, regardless of changing social circumstances. However, then it is not possible to diagnose and determine the criterion that would allow us to differentiate cases of ethos 
betrayal from instances of new ethos creation. Thus the possibility of an unbiased moral evaluation of ethos disappears as well. On the other hand, the idea of attributing the universal and everlasting application to the values and rules comprising the ethos making them completely independent from social circumstances is at odds with universal intuition and historical and sociological observations that demonstrate that the phenomenon of changes occurring in the ethos throughout history cannot be questioned. It seems that in order to avoid the above-mentioned difficulties one ought to acknowledge that ethos continuity does not rule out its transformation. This is true provided that the structural uniformity of the lifestyle core of a particular community is preserved in the process of transformations (Goćkowski, Hołowiecka 1981) ${ }^{1}$. Indeed, the problem is only moved to a different level, namely the level of establishing which values should create the nucleus of the ethos. Nevertheless, one can attempt to solve the issue applying the temporality criterion - the longer a particular value or norm is accepted by members of an ethos group the more it deserves a position in the core, or the more the position is reinforced. Therefore quoting J. Goćkowski it should be assumed that: "ethos is (..) a structure and at the same time a process. Being a structure it remains static for the sake of the cultural identity of a community that defines itself through the identity. The idea of ethos being a process consists in adapting it to conditions and requirements and also in improving for the purpose of being near perfection" (Goćkowski 1998, p. 302) $)^{2}$.

From the quoted definitions it appears that ethos is an axionormative system that reflects the types of behaviour and attitudes assumed by members of a given community and set by a certain group of values and goals. Ethos manifests itself in accepted role models and social roles. It results from socialisation, the process of education and upbringing according to definite principles. It should be underlined that a subject of ethos values is a particular community, koinonia indicating a specific axiological order. This model has been accepted by numerous researchers (e.g., Ossowska 1973; Goćkowski 1993; Szawiel 1982) and will also be accepted in this disquisition. At the same time, the thesis omits the individualist variant of ethos perspective consisting of treating an individual as a subject of an ethos.

\footnotetext{
${ }^{1}$ There is no way not to associate the conception of a core of ethos that is proposed by the authors with the conception of the scientific research programmes created by I. Lakatos. According to his theory the scientific research programs consist of a hard nucleus formed by irrevocable statements decided upon by academics and a row of protective hypotheses containing statements that can be rejected (Lakatos 1999).

${ }^{2}$ One should pay attention to a certain terminological inadequacy that is apparent in the quoted fragment. A structure is a system of linked components of a particular object or set. Whereas a process can be defined as transformations happening within a given system (compare Kopaliński 1989, p. 413 and p. 483). Thus the notion of a process should be replaced rather by the term of dynamic structure that appears to aptly reflect the author's intuitions.
} 


\section{The ethos of scholars}

The above deliberations concerning the notion of ethos lead to the following conclusion: ethos as a rule of co-existence that is typical for a particular community is marked by universality of being a binding force (within a given group) and the possibility of evolving in accordance with transformations occurring in an ethos community. The fundamental question that directs our research to the present point of deliberation can be formulated in this way: what sorts of values does the academic ethos consist of and under what axionormative order are members of the koinonia of the learned?

The ethos of scholars had its origin in times of medieval learning when the first universities were established gathering certain types of individuals (creators and teachers of knowledge) supporting common goals, and principles of accomplishing them. J. Goćkowski and L. Hołowiecka describe ethos of scholars as: "the style of professional life of the creators and teachers of science that has become the acknowledged and assimilated everyday practice, everyday style of thinking and acting of scholars as scholars" (Goćkowski, Hołowiecka 1981, p. 165).

According to the authors, the academic ethos developed no earlier than the XIX century. It consisted of the values such as: truth, knowledge, method, cognition, creative work, self-realisation, education of scholars, freedom to conduct research and to publish its results. Along with the values there was a noticeable development of certain imperatives standardising the conduct of the whole academic community: the imperative for treating scientific cognition as an autotelic value, the imperative for solid and just academic criticism, the imperative for tolerance and open attitude, the imperative for education and upbringing of young students, the imperative for responsible and disinterested conducting of research. The ethos formed on the basis of the above principles and moral norms performed the tiestrengthening, culture-forming, inspiring, controlling, shaping, educating, psychotherapeutic and warranty function (Goćkowski, Hołowiecka 1981).

Are the values forming the traditional ethos (truth, diligence, criticism, tolerance, open-mindedness, disinterestedness, responsibility, etc.) reflected in the ethos of contemporary scholars? Taking into consideration results of the diverse attempts to codify the academic ethos, it can certainly be admitted that these values are present at least in verbal declarations. In the nascent academic codes and sets of rules and also during symposia and conferences devoted to the issue of morals of the academic milieu it is being constantly stressed that it is significant to disinterestedly aim at finding truth as a constitutive value for the ethos of scholars (e.g., Shils 1983; Fudalej 1991). Additionally, scholars draw attention to 
the need for solid and just criticism (e.g., Siegel 1988; Passmore 1980). At the same time they need to shoulder responsibility for their research and the process of educating junior academics (e.g., Macfarlane 2004; Markie 1994; Nisbet 1977). Thus principles comprising the ethos of scholars have remained unchanged. Nonetheless, we hear of "a bad condition of the general sense of the academic ethos" (The Committee for Ethics in Science PAN 2001, p. 4), more and more we hear of cases of conduct that is at variance with the ethos (e.g. Markie 2003; Macrina 1995). Goćkowski and Hołowiecka track the causes of this "bad condition" in the disappearance of the traditional ethos for the sake of pluralism of sorts of scholars' ethos that has its source in varied views on one's career (Goćkowski, Hołowiecka 1981) a multitude of ethoses weakens the bonds between academics (to a great extent they are driven by self profit and not by the best interests of learning) and gives rise to conflicts in the area of moral decisions, distorts academic debate and critical attitude. Gradual decline of the traditional ethos of scholars also influences the forming of morally negative attitudes of a scholar towards the youngest members of an academic community. The issue of a scholar's abuses occurring in the process of educating learners is extensive. Therefore, in a further section of this article I would like to focus only on this one aspect - abuses by the thesis supervisor.

\section{Abuses by the thesis supervisor}

For the sake of deliberation of abuses by the thesis supervisor it is necessary to define abuses (pathologies) as "kinds of withdrawal from faithfulness to the principles and commandments of the academic ethos" (Goćkowski 1994, p. 28). This work is going to deal with the above-mentioned abuses in the context of the values forming the ethos of scholars. I am going to concentrate on the following values: responsibility, tolerance and freedom of thought, justice and objectivity, intellectual honesty and independence of thinking, having in mind that the abuses discussed in the context of a given value are on many occasions acts of betrayal of other values as well.

\section{Responsibility}

By virtue of their performed functions (of researcher, teacher and person who popularizes knowledge) scholars are responsible to the academic community, their students and to society. A scholar as a university teacher is responsible not only for passing on knowledge in a competent way, but also for developing students' technical skills and indicating what the appropriate practice of academic method consists of. By means of their expertise in a particular field and factual knowledge scholars must inspire students' trust and 
belief that the knowledge learnt would extend their competence and prepare them for a profession and function within society. From the very beginning scholars should also acquaint their students with the rules of conducting and describing research, using quotations and writing bibliographies and reviewing other papers which support development of a sense of responsibility. They ought to teach learners how to undertake academic criticism and how to avoid exposing themselves to ridicule so that in the course of future work young researchers would know exactly how to conduct solid academic research. A scholar is also responsible for correcting students' transgressions against generally accepted norms, as if not corrected, any mistakes that occur at this stage can affect the quality of their subsequent work . It is necessary for a scholar to aim at becoming: "a tutor teaching professional ethos. Performing this function most frequently consists in teaching norms, providing with recommendations and advice, and how to abide by them, also in providing students with a good role model by virtue of own conduct" (Goćkowski 1984, p. 324).

Considering present mass education, it must be noted that a thesis supervisor is even more responsible for intellectual and moral development of junior research workers than other academic teachers. It is because he is the one who is in contact with students individually, that consequently enables him to establish a personal bond and assist them with any academic dilemmas.

In the light of the aforementioned duties resulting from scholars' responsibility to their students it is worthwhile to touch upon the issue of two phenomena that are present in contemporary higher education: multiple -employment and the practice of supervising many theses at the same time.

The first phenomenon is becoming more and more common due to the rapid increase in the number of private colleges and universities. As W. Chmielewski remarked at present "there are less and less people with post-doctoral degree and professors working only for one school or without fee-for-task agreements" (Chmielewski 1999, p. 46). The indisputable and certainly most frequently considered reason for this is the opportunity to earn a higher salary or to widen the circle of students and expand the range of personal academic influences. However, the number of duties connected with this sort of intensified teaching, administration, and also with conducting own research may result in a lack of time and stamina to honestly fulfill all three functions. As a result, particularly those duties that are not forced onto a scholar by the fixed schedule are affected. These are obligations that do not have to be accounted for. Among them there is the supervision of masters and doctoral theses. A supervisor working full-time for numerous educational institutions is not able to control 
and systematically correct subsequent sections of theses, not to mention arousing students' interest in the scholar's own research, providing he does it at all, in the whirl of other obligations (Weil, Arzbaecher 1997). The contact between a student and a supervisor becomes reduced to an absolute minimum. Thus it is not possible to form the master-disciple bond that is believed to be "the essence of intellectual co-operation at university" (Pelc 2006, p. 177) or to educate through personal influence. Moreover, the supervisor's actions against the moral imperative for responsibility to the academic community and their students may become a negative model and a point of reference for junior researchers that accompany them. Pelc wrote that: “(...) junior academic workers and students can learn from their supervisor that for the sake of income it is acceptable to abandon attention to their own work and to previously undertaken obligations. They may also count on 'taking jobs on the side'. It would be awkward for their tutor to point out that they have neglected their duties. Consequently the sheer work, ethos of work and morals of a group would get affected" (Pelc 2006, p. 178).

It is analogical with regard to supervising numerous theses at the same time. Is a single thesis supervisor capable of providing academic supervision over a considerable number of papers? It would seem to be impossible, as the procedure of essential and linguistic correction alone requires from the supervisor the devotion of a lot of time for profound reflection and the making of proper corrections to a text. If these duties are not fulfilled, the following situation may occur: "After two years of work on his dissertation a student is forced to change its subject or even a supervisor because the undertaken research has turned out to be unfeasible due to insufficient sources and inappropriate method. It is now necessary to radically change the concept of the paper, to conduct new research, to prolong studies, etc. which is incredibly harmful for the student and undermines the scholar's authority in this particular community" (Walentynowicz 1977, p. 86).

If one assumes that a moral duty of responsibility to students involves the necessity of teaching, educating and training new researchers "certain qualities that are characteristic for an academic worker and at the same time for everybody who in the society holds a position requiring university education" (Czeżowski 1946, p. 52), then in terms of the principles of responsibility abuses by a scholar, and a thesis supervisor in particular, are multiple employment, the practice of supervising simultaneously too many theses and any other supervisory activity that stems from disrespect of these values. 


\section{Tolerance and the freedom of thinking}

Tolerance as a value within the scholars' ethos manifests itself in attentive listening to others' opinions even to those contradictory to the universally accepted ones and in particular to our own personal ones (Hare 1963; Ossowska 1983). In terms of a supervisor's responsibility this quality reflects itself in respect for students' interests, research concepts and autonomy. Obviously it does not equate to allowing complete freedom of voiced opinions and choice of the research area. It stands for the need to prove certain: "internal intellectual humbleness that (...) enables favourable listening to youthful theoretical ideas and factual cooperation with young researchers on level terms and at the same time allows (...) to retain solemnity and importance of one's age, knowledge and experience" (Ingarden 1967, p. 202).

The opposite of such behaviour is a peculiar sort of paternalism and authoritarian treatment of the student. Similarly, the lack of interference in the student's work provokes undesirable effects, just as its excess (that can be driven by good intentions) destroys "independence of thought and courage of conviction" (Czeżowski 1946, p. 313). Sometimes it happens that supervisors perceive a student's active and independent attitude as dangerous for their own authority and intellectual advantage. As a result, by means of persistent care a scholar can thwart the efforts of a student. It is a betrayal not only of the principle of tolerance and freedom of thought, but also of kindliness that should be abided by every scholar.

The issue that seems to be highly debatable and not subject to assessment is when a supervisor imposes certain subject matter on a student participating in the work of a group of researchers managed by the supervisor. In this case the supervisor does not have his own interests in mind but is driven only by certain reasons of a science. What about an order to abandon a research area that was previously selected on student's own and being that student's first own attempt at academic writing in favour of elaborating on subject matter established arbitrarily by a supervisor? Is it not an indication of ignoring a young researcher's eagerness and passion for learning, the expression of unduly influencing a student to suit a technical plan of a group supervisor and at the same time curbing a student's development as an independently thinking academic? On the other hand, cannot the supervisor put forward his arguments (arguments of an experienced researcher) against needs of a young debutant researcher? The issue appears not to have a straightforward solution.

\section{Justice and objectivity}

Justice is one of the major values outlining the rules of social co-operation. It plays a fundamental role in the proper functioning of the scientific world. A university is even 
called a higher school of justice, engaged in practical study of its recognition, and defining, using and respecting its principles. A fair act is related to objectivity that T. Czeżowski defines as not yielding in one's evaluation and research to other respects, but only to the principles of academic criticism (Czeżowski 1946).

A thesis supervisor assumes attitudes that are at variance with the imperative for justice and objectivity when he approves of non- factual assessment of students' work, facing intellectual idleness, assigning own duties to students and accepting lack of criticism. With regard to the above comments the abuse of the principle of justice and objectivity amounts to exploitation of students at teaching, especially using them in examining and correcting papers of younger colleagues (Martin 1986). Obviously it may be deemed appropriate to introduce a young academic to the rules of assessment and academic proofreading, but it cannot be done without supervision and at expense of overwhelming students or using them as "cheap labour".

As in the discussed case of reducing the student's independent activity in order to maintain the scholar's own authority and also in the context of the abuses under consideration it is necessary to pay attention to the practice of slowing down and blocking the development of other academic employees caused by jealousy and fear of losing one's own position . Assigning time-consuming and useless research or overwhelming with an excess of teaching appears to be aimed at discouraging an able student from creative work and consequently disqualifying him as a future prospective rival in a struggle for a university post. Scholars tend to invest time and funds in favour of average students who would not aspire to become their successors. Reality seems to be contradictory to Marczewski's words that "for a good master it is a reason for happiness and pride when a student begins to surpass him" (Marczewski 1967, p. 110).

Another issue that needs to be raised in relation to justice and objectivity concerns the rapidly growing mass production of diplomas. It gives rise to actions aimed at supporting as many theses as possible regardless of their academic quality. The large number stimulates the growth of the attractiveness of a particular university or college. As a result, more and more prospective 'clients' get attracted to a school and a supervisor gains (only superficial and apparent) increase in prestige. However, in reality this procedure creates favourable conditions for weak dissertations not written under proper responsible supervision and not having undergone solid and unbiased criticism. Approval of such papers results in the lowering of standards of science and devaluation of diplomas, just as in the case of a supervisor performing the function as a factual writer of a thesis apparently written by a 
student. A thesis supervisor can have a dilemma as to whether he ought to support a work that is very poorly thought-over or just mediocre, for the sake of the development of a researcher's learning or should he stop a student's career even at the expense of thwarting plans or even at a risk of a student's nervous breakdown. Additionally, there is the possibility of creating conflict with the other members of the academic board. The same situation, perhaps to an even greater extent, is connected with the supporting of master theses that nowadays are hardly ever rejected by supervisors and boards as it is commonly assumed that a master's degree is at everybody's fingertips. M. Grabowski comments on it in a very vivid way: "We are getting involved in a very dangerous practice. It is just as if we taught the violin to dullwitted and tone-deaf people. They will always saw away and we make them believe that they are musicians by giving them diplomas" (Grabowski 1999, p. 70).

Analogically, while taking into account doctoral dissertations one can come up with the conclusion that "tomorrow's doctoral theses will be worth as much as today's master's ones" (Brzeziński 2002, p. 30).

All the above-mentioned and described pathologies: exploiting students, hindering their academic work, collaborating and contributing to awarding unmerited diplomas, constitute a betrayal of the principles of justice and objectivity.

\section{Intellectual honesty and the independence of thought}

A scholar who is in concurrence with the value of intellectual honesty: "not only should admit one's doubts or lack of knowledge but also should be prepared to withdraw one's statements when new research proves their insufficient legitimacy" (Okoń 1973, p. 117).

Whereas autonomy of thinking consists in using one's own intellectual resources, ideas and conceptions to search for the truth: "even though that would require overcoming one's indolence, love of comfort and would involve lots of effort, sacrifice, and exposing oneself to loss, also the financial one" (Czeżowski 1946, p. 312-313).

A supervisor's disrespect for these values may lead to abuses that need to be diagnosed.

An abuse is a fact of undertaking the supervision of theses dealing with subject matter that exceeds the supervisor's own factual competence. In other words, a given scholar driven either by willingness or personal interests (meaning the necessity of promoting a certain number of postgraduates or doctors or else maintaining one's own academic authority) does not evaluate conscientiously and critically his/her own knowledge and capabilities. 
Consequently, such a person agrees to commit him or herself to assisting a student and giving him the illusory impression of professional preparation. Similar vanity, hubris and inability to admit one's own insufficient knowledge can harm a student who has trusted his supervisor's competence and relies on responsible guidance on the part of a teacher.

The above deficiencies of morality can also contribute to the practices of a scholar's appropriating his students' research results. The issue concerns cases of plagiarism and insisting on co-authorship of a paper or research carried out under his guidance. The phenomenon of plagiarism - presenting as one's own whole fragments of text written by another author (Maddox 1995; Bouville 2008; Loui 2002) - is evident enough to conclude that it does not require lengthy comments. It is a flagrant violation of the principles of the academic ethos and law at the same time. Nonetheless, the fact of a supervisor copying fragments of his/her own students' theses appears to be quite common. On the other hand, the issue of co-authorship is deemed to be quite controversial. Does a supervisor have a moral right to publish his student's research results also as his/her own? Some time ago Infeld criticised "the mania of adding one's surname to the works of junior colleagues" (Infeld 1967, p. 101). Nowadays the practice is still observed and taking place, especially in the field of natural science where research is conducted by a group of many people and at times it is difficult to determine the factual extent of each person's participation in an experiment. The result is that it leads to abuses on the part of team members who have not at all or hardly contributed to the accomplished outcomes ${ }^{3}$. Sometimes it happens that a supervisor makes a considerable contribution to his student's research. Can he on this occasion rightfully demand to put his name among the names of authors and can he treat somebody else's creativity as his own? Or should it not be rather acknowledged that the scholar was only fulfilling his duties for which he should not expect any additional profit? In the arts the proper guidance over a dissertation should exclude possibility of co-authorship in the event of its potential publication. It is different in natural science - publishing a thesis under the name of a student and his supervisor is a standard procedure. However, it is worthwhile to mention that the stand of the Committee on Ethics in Science is unequivocal in this matter: "However large a supervisor's contribution to working on the conception of a master's thesis is, it is a student writing it who should be considered its author" (http://kbn.icm.edu.pl/etyka/stan_0625.html).

\footnotetext{
${ }^{3}$ At this point one can use the example of the procedure of adding the name of an institute director to the list of thesis authors only because he is performing such function.
} 


\section{Conclusions}

The deliberations presented in this work constitute an attempt to systematise the subject matter of the academic ethos related to issues of a thesis supervisor's ethics. All of the arguments point to the following conclusions:

1) The gradual disappearance of an academic ethos and at the same time lack of a new one create favourable conditions for multiple varieties of ethos (ethos groups) to appear. These varieties cause a weakening of the bonds cementing the world of academics, lowering their ethical standards and simultaneously increasing pathological attitudes of academics.

2) Regardless of external pressure and temptations these pathologies are "a testimony of a process of a breakdown of values occurring inside the world of scientists. As nobody, except themselves, is able to corrupt the mind, demoralise the conscience and pervert the work of a researcher and teacher" (Goćkowski 1994, p. 28).

3) The process of this devaluation manifesting itself in pathological attitudes of the members of academic koinonia wields a particularly negative influence on the forming of interpersonal relationships between the university teacher and students and between a thesis supervisor and his student.

4) Supervisor's transgressions against their ethos are characterized by disrespect for qualities such as responsibility, tolerance, freedom of thinking, justice, objectivity, intellectual honesty and the independence of thought.

5) Among the repercussions of irresponsible supervisor guidance for students is the formation of attitudes such as: lack of responsibility for their own academic practice, imitating supervisor abuses or being discouraged to continue an academic career. As Brzeziński aptly notices, "the set of academic values is unfamiliar to a student for who and when could introduce it to them, help to understand it and show the way of its accomplishment?” (Brzeziński 2002, p. 37).

Bibliography:

Baradziej J., Goćkowski J. (eds.) (1998), Rozważania o tradycji i ethosie: praca zbiorowa, Wydaw. Baran i Suszczyński, Kraków.

Bouville M. (2008), Plagiarism: Words and Ideas, ”Science and Engineering Ethics", 3. 
Brzeziński J. (2002), Erozja norm akademickich. Próba diagnozy, [in:] Gruszka B. (ed.), Uczeni i uczelnie w III Rzeczypospolitej. Nowe wyzwania i zagrożenia, Fundacja na Rzecz Nauki Polskiej, Warszawa.

Chmielewski W. (1999), Uwagi w sprawie nauki i nauczania przez współudział w badaniach, [in:] Majkowska-Sztange A. (ed.), Nauka i nauczanie, Fundacja na Rzecz Nauki Polskiej, Warszawa.

Curren R. (ed.) (2003), A Companion to the Philosophy of Education, Blackwell Publishing, Malden.

Czeżowski T. (1946), O uniwersytecie i studiach uniwersyteckich, Wyd. Uniwersytetu Mikołaja Kopernika, nakładem Księgarni Naukowej T. Szczęsny i S-ka, Toruń.

Elliot D., Stern J.E. (eds.) (1997), Research Ethics: A Reader, UPNE, Hanover.

Fudalej M. (1991), Techniki i typy kłamstwa w nauce, [in:] Goćkowski J., Pigoń K. (eds.), Etyka zawodowa ludzi nauki, Zakł. Nar. im. Ossolińskich, Wrocław.

Goćkowski J., Hołowiecka L. (1981), Ethos profesjonalny uczonych, ’Etyka”, 19.

Goćkowski J., Pigoń K. (eds.) (1991), Etyka zawodowa ludzi nauki, Zakł. Nar. im. Ossolińskich, Wrocław.

Goćkowski J., Sikora M. (eds.) (1993), Modele nauki: studia z zakresu filozofii i socjologii nauki, Wydaw. Nauk. IF UAM, Poznań.

Goćkowski J. (1993), Perspektywa ethosowa w socjologii nauki, [in:] Goćkowski J., Sikora M. (eds.), Modele nauki: studia z zakresu filozofii i socjologii nauki, Wydaw. Nauk. IF UAM, Poznań.

Goćkowski J. (1994), Patologia i terapia życia akademickiego w perspektywie etosowej, [in:] Zieliński J., Tyszkiewicz L. (eds.), Etyka w środowisku akademickim, PAN, Warszawa.

Goćkowski J. (1998), Grupy ethosowe świata ludzi nauki, [in:] Baradziej J., Goćkowski J. (eds.), Rozważania o tradycji $i$ ethosie: praca zbiorowa, Wydaw. Baran i Suszczyński, Kraków.

Grabowski M. (1999), Głos w dyskusji, [in:] Majkowska-Sztange A. (ed.), Nauka i nauczanie, Fundacja na Rzecz Nauki Polskiej, Warszawa.

Gruszka B. (ed.) (2002), Uczeni i uczelnie w III Rzeczypospolitej. Nowe wyzwania $i$ zagrożenia, Fundacja na Rzecz Nauki Polskiej, Warszawa.

Herbut J. (1997), Leksykon filozofii klasycznej, TN KUL, Lublin.

Hook S., Kurtz P., Todorovich M. (eds.) (1997), The Ethics of Teaching and Scientific Research, Prometheus Books, New York. 
Infeld L. (1967), Czego się nauczyłem uczac? [in:] Matejko A. (ed.), Kierowanie praca zespołowa w nauce. Materiały z Sympozjum Naukoznawczego Jabłonna 21-22 maja 1965 r., PWN, Warszawa.

Ingarden R. (1967), O wychowywaniu uczonych, [in:] Matejko A. (ed.), Kierowanie praca zespołowa w nauce. Materiały z Sympozjum Naukoznawczego Jabłonna 21-22 maja 1965 r., PWN, Warszawa.

Kopaliński Wł. (1989), Stownik wyrazów obcych i zwrotów obcojęzycznych (16th ed.), PWN, Warszawa.

Lakatos I. (1999), The Methodology of Scientific Research Programmes, Cambridge University Press, Cambridge.

Leja L. (ed.) (1977), Dydaktyka Szkoły Wyższej, Wydaw. Nauk. UAM, Poznań.

Loui M.C. (2002), Seven Ways to Plagiarize: Handling Real Allegations of Research Misconduct, "Science and Engineering Ethics", 8.

Macfarlane B. (2004), Teaching with Integrity: The Ethics of Higher Education Practice, Routledge, London.

Macrina F.L. (1995), Scientific Integrity: An Introductory Text with Cases, ASM Press, Washington.

Maddox J. (1995), Plagiarism Is Worse Than Mere Theft, "Nature", 6543.

Majkowska-Sztange A. (ed.) (1999), Nauka i nauczanie, Fundacja na Rzecz Nauki Polskiej, Warszawa.

Marczewski E. (1967), Dziesięć przykazań, [in:] Matejko A. (ed.), Kierowanie praca zespołowa w nauce. Materiały z Sympozjum Naukoznawczego Jabłonna 21-22 maja 1965 r., PWN, Warszawa.

Markie P.J. (ed.) (1994), A Professor's Duties: Ethical Issues In College Teaching, Rowman \& Littlefield Publishers, Lanham.

Markie P.J. (1994), To Be a Professor, [in:] Markie P.J. (ed.), A Professor's Duties: Ethical Issues In College Teaching, Rowman \& Littlefield Publishers, Lanham.

Markie P.J. (2003), The Professor-Student Relationship and the Regulation of Student Life, [in:] Curren R. (ed.), A Companion to the Philosophy of Education, Blackwell Publishing, Malden.

Martin B. (et al.) (1986), Intellectual Suppression: Australian Case Histories, Analysis and Responses, Angus \& Robertson, Sydney.

Martin B. (1986), Academic Exploitation, [in:] Martin B. (et al.), Intellectual Suppression: Australian Case Histories, Analysis and Responses, Angus \& Robertson, Sydney. 
Matejko A. (ed.) (1967), Kierowanie praca zespołowa $w$ nauce. Materiaty z Sympozjum Naukoznawczego Jabłonna 21-22 maja 1965 r., PWN, Warszawa.

Nisbet L. (1977), The Ethics of the Art Of Teaching, [in:] Hook S., Kurtz P., Todorovich M. (eds.), The Ethics of Teaching and Scientific Research, Prometheus Books, New York.

Okoń W. (1973), Elementy dydaktyki szkoty wyższej, PWN, Warszawa.

Ossowska M. (1973), Ethos rycerski i jego odmiany, PWN, Warszawa.

Ossowska M. (1983), O człowieku, moralności i nauce: miscellanea, PWN, Warszawa.

Ossowska M. (1983), Wzór obywatela w ustroju demokratycznym, [in:] Ossowska M., O człowieku, moralności i nauce: miscellanea, PWN, Warszawa.

Passmore J. (1980), The Philosophy of Teaching, Harvard University Press, Cambridge.

Pelc J. (2006), Korabielnikowcy w szkolnictwie wyższym, "Przegląd Humanistyczny", 5-6.

Shils E. (1983), The Academic Ethic, University of Chicago Press, Chicago.

Siegel H. (1988), Educating Reason. Rationality, Critical Thinking and Education, Routledge, New York-London.

Szawiel T. (1982), Struktura społeczna i postawy a grupy etosowe, "Studia Socjologiczne", $1-2$.

The Commitee of Ethics in Science PAN (2001), Dobre obyczaje w nauce. Zbiór zasad $i$ wytycznych, 3ed, PAN KEwN, Warszawa.

Walentynowicz M. (1977), Prace magisterskie i dyplomowe, [in:] Leja L. (ed.), Dydaktyka Szkoły Wyższej, Wydaw. Nauk. UAM, Poznań.

Weil V., Arzbaecher R. (1997), Relationships in Laboratories and Research Communities, [in:] Elliot D., Stern J.E. (eds.), Research Ethics: A Reader, UPNE, Hanover.

Zieliński J., Tyszkiewicz L. (eds.) (1994), Etyka w środowisku akademickim, PAN, Warszawa.

Netography:

Stanowisko opiniodawczo-doradczego Zespołu do spraw Etyki w Nauce z 20 września 2001 r., http://kbn.icm.edu.pl/etyka/stan_0625.html, retrieved: 23.11.2008. 